Amrah Y.Al-Jmmal

BDS,MSc, (Asst. lec.)

\section{Metal Ion Release From Ni-Cr Alloy with Different Artificial Saliva Acidities}

Department of Prosthetic Dentistry

College of Dentistry, University of Mosul

$$
\begin{aligned}
& \text { الخلاصة } \\
& \text { الأهداف: تحف الدراسه الى تقيم تأثير تغير درجة حامضية اللعاب على تحرير الايونات المعدنية من سبيكة نيكل-كروم بازمنة مختلفة وكذلك حساب كمية ايونات }
\end{aligned}
$$

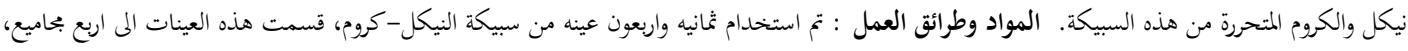

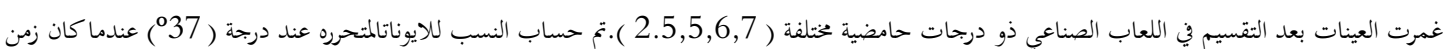

$$
\begin{aligned}
& \text { الغمر(36,24,12 يوما وذلك باستخدام مطياف الامتصاص الذري. النتائج : بينت نتائج تحرر ايونات النيكل والكروم احصائيا ان هناك فرق معنوي عند }
\end{aligned}
$$

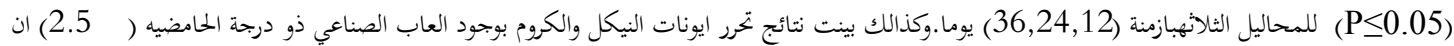

$$
\begin{aligned}
& \text { معدل تحررها اكبر من بقية المحاليل الاخرى ذات (5,6,7) (أزمنة الغمر المختلفه. الاستنتاجات : هنالك دليل من خلال النتائج ان هناك تحرر لايونات النيكل } \\
& \text { والكروم اللعاب الصناعي ذات درجات حامضيه مختلفه . وكذلك بينت النتائج بأن معدل تخرر ايونات النيكل والكروم بنسب عاليه في العاب الصناعي ذو درجة } \\
& \text { حامضة (2.5). ولاكن معدل تحرر ايونات النيكل اكبر من تحرر ايونات الكروم عند غمرها بللعاب الصناعي ذو درجات حامضيه غختلفه. }
\end{aligned}
$$

\begin{abstract}
AIMS: evaluate the effects of changes in salivary $\mathrm{pH}$ on ion release from the $\mathrm{Ni}-\mathrm{Cr}$ alloy at different time and calculate the amount of nickel, chromium ions released from these alloyes.MATERIALS AND METHODS: Fourty eight specimens of Ni-Cr alloy were divided, four specimens immersed in each of four types of artificial saliva at different $\mathrm{pH}$ (7 as control,6,5 and 2.5), in three storage periods (12, 24 and 36days). All test tubes were incubated at $37^{\circ} \mathrm{C}$. After the immersion time was finished the quantities of metallic ions released for $\mathrm{Ni}$ and $\mathrm{Cr}$ were measured for each test solutions after 12, 24and 36days of immersion by atomic absorption spectroscopy. REULTS: The results of Nickel and Chromium ion release showed a statistically significant difference at $\mathrm{p} \leq 0.05$ between three immersion solutions after $(12,24,36)$ days, artificial saliva $(\mathrm{pH} 2.5)$ showed higher rate of $\mathrm{Ni}$ and $\mathrm{Cr}$ release than artificial saliva ( $\mathrm{pH} 7$ as control $, 6,5)$ after various immersion times. It should mention the nickel ion release has been found to be more than chromium ion release. CONCLUSIONS: There is an evidence that the $\mathrm{Ni}$ and $\mathrm{Cr}$ ions release from $\mathrm{Ni}-\mathrm{Cr}$ alloy at the presence of different acidity of artificial saliva. Chromium and nickel ion release in small amount in artificial saliva with $\mathrm{pH}(6,5)$, while in $\mathrm{pH} 2.5$ release in large amount after $(12,24,36)$ days of immersion. Nickel exhibited the highest level of ion release than Cr.
\end{abstract}

Key words: Corrosion, ion crelease, Ni-Cr alloy.

Al-Jmmal AY,Metal Ion Release From Ni-Cr Alloy with Different Artifitial Saliva Acidities. AlRafidain Dent J. 2014; 14(2):266-271.

Received: 5/5/2013 Sent to Referees: 7/5/2013 Accepted for Publication:25/6/2013

\section{INTRODUCTIONS}

Dental casting alloys with high and low noble metal contents are widely used in dentistry, nickel-chromium dental casting alloys were developed as an alternative to gold based alloys for partial dentures and crowns, in part because of their superior properties in porcelain fused to metal applications. ${ }^{(1,2)}$

Corrosion may be described as the deterioration of materials by aggressive action of the environment and the oral environment is conducive to corrosion. Factors that may initiate corrosion include the quantity, quality and $\mathrm{pH}$ value of secreted saliva (which are affected by the diet and intake of medicines ordrugs),intake of organic acids commonlyfound in foods and beverages (such as lactic, acetic, malic, oxalic,tartaric, and carbonic acids), and accumulation of dentalplaque. ${ }^{(3)}$

Several studies have reported on the release of metallic ions from base dental casting alloys under differing $\mathrm{pH}$ conditions which simulated the oral cavity. A low $\mathrm{pH}$ environment acidic conditions increases the release of metallic ions from 
dental alloys, this effect is especially pronounced for nickel based alloys. Dental plaque often adheres to dental alloys and creates a low $\mathrm{pH}$ environment locally. This condition promotes the corrosion of dental alloys. ${ }^{(4,5,6)}$

Atomic absorption spectrophotometer was used to measure the amount of ion release; atomic absorption is a technique based on the unique spectrum of each element. ${ }^{(7)}$ We aimed to evaluate the effects of changes in salivary $\mathrm{pH}$ on ion release from the $\mathrm{Ni}-\mathrm{Cr}$ base alloy at different time intervals, and calculate the the amount of nickel and chromium ions released from this alloy.

\section{MATERIALS AND METHODS}

The dental casting alloy used in this study is nickel chromium alloy ( Bremen, Germany). The chemical composition of this alloy is given in Table(1). The samples were designed according to ADA specification No. 14 (ADA, 1995) $(20 \times 10 \times 0.6) \mathrm{mm} \pm 0.1$, fourty eight rectangular casting alloy specimens were fabricated. The wax pattern was constructed using base plate wax (Plastodentse, Degussa,Germany).The wax was sprued, invested and cast in phosphate bonded investment material (Accufit,Cleveland, $\mathrm{OH}$ ) using a conventional lost wax technique. All processes of wax pattern, investment, burn out and casting were carried out according to the manufacturer's instructions.

Table (1): Composition of dental alloy for ceramics on nickel base .

\begin{tabular}{cccc}
\hline $\mathbf{N i}$ \% & $\mathbf{C r} \%$ & $\mathbf{M o \%}$ & $\mathbf{S i} \%$ \\
\hline 62 & 26 & 11 & 1,5 \\
\hline
\end{tabular}

Finishing of the casting:

The major portion of the investment was gently removed. The all casted specimens were carefully cleaned using $50-\mu \mathrm{m}$ aluminum oxide air borne particle abrasion for 15 second to remove investment debris. The specimen were machined with carborandum wheels, special stone burs rubber wheels and then the specimens were ground wet with 180, 400, 600, 800,1000 and 2000 grit silicon carbide papers. After this steps a high speed polishing grinder machine (Denta rapid, Germany) with rouge material were used to obtain smoother and mirror surface. This is done according to the manufacture instructions, then ultrasonically cleaned in ethanol for $15 \mathrm{~min}$ and washed with distilled water. ${ }^{(8)}$

Immersion solutions:

The conditioning media used in this test was artificial saliva with different $\mathrm{pH}$ (7as control,6,5 and 2.5) made in the laboratory, the composition artificial saliva was $7.69 \mathrm{~g}$ of K2HPO4, $2.46 \mathrm{~g}$ of $\mathrm{KH} 2 \mathrm{PO} 4,5.3 \mathrm{~g}$ of $\mathrm{NaCl}$, and $9.3 \mathrm{~g}$ of $\mathrm{KCl}$ added to $1,000 \mathrm{~mL}$ of distilled water. To prepare artificial saliva with different $\mathrm{PH}(6,5$ and 2.5), by adding lactic acid ,and by adding $\mathrm{NaOH}$ was obtain $\mathrm{pH} 7$ (control). After the $\mathrm{pH}$ values were adjusted to their desired levels using lactic acid and $\mathrm{NaOH}$, they were measured using a pH meter (Philips PW 9422). The PH 2.5 solution was used to test the extreme conditions of short term $\mathrm{pH}$ variances, examples of causes of short term $\mathrm{pH}$ variances include the intake of acidic beverages. The $\mathrm{pH}(5,6)$ was used to test $\mathrm{pH}$ variances arising from long term exposure, such as that of daily saliva. ${ }^{(6,10)}$

Immersion times:

Application time correspond to the accumulated periods of regular usage of the partial denture, so when the patient wear the denture ten hours (as average amount) in the day,12 day time correspond to the acumulated effect of regular usage of the partial denture for one months and 24 day,36 day time correspond to the acumulated effect of regular usage of the partial denture for two and three months respectively. These immersion periods seems to be too shorter cumulative periods. ${ }^{(11)}$

Immersion test:

Fourty eight specimens of Ni-Cr alloy were divided, four specimens immersed in each of four types of artificial saliva ( $\mathrm{PH}$ 7,6,5 and 2.5),in three storage period (12, 24and 36days). Metal specimens were coded, washed in distilled water and 
alcohol, and then immersed in polypropylene tubes containing $15 \mathrm{~mL}$ of artificial saliva of each test solution. To monitor the release of metallic ions into the immersion solutions in polypropylene tubes, control test tubes containing immersion solutions only were also prepared. All test tubes were incubated at $37^{\circ} \mathrm{C}$, after the immersion time was finished the quantities of metallic ions released for $\mathrm{Ni}$ and $\mathrm{Cr}$ were measured for each test solutions after 12 , 24and 36days of immersion. Atomic absorption spectroscopy absorbance readings per element were made for each sample. Each reading was used to determine the mean concentration of the different elements in part per million (ppm) released from the alloys.

By SPSS statistical program we obtained: 1) Descriptive statistics includes, mean and standard deviation values.2) ANOVA, Duncan and Dunnett'smultiple range test were used. The statistical results were con- sidered

significant at $\mathrm{p} \leq 0.05$.

\section{RESULTS}

A-Chromium ion release :

The value of mean of $\mathrm{Cr}$ ion release (pmm), \pm standard deviation, Dennett's test and Duncan Multiple analysis rang test of control, and three immersion solutions of artificial saliva with different $\mathrm{pH}$ (7as control, 6, 5 and 2.5) after various immersion times are shown in Figure (1). After 12, 24 and 36 days of immersion, $\mathrm{Cr}$ ion release in small amount in solution with $\mathrm{pH}(6,5)$ respectively, while in $\mathrm{pH} 2.5$ release in large amount $(0.860,0.896,0.962 \mathrm{ppm})$ respectively when compare with control pH7 as shown in Figure(1) Cr ion release showed a statistically significant difference at $p \leq 0.05$ between three immersion solutions after various immersion times as shown in Table (2).

\section{4 days immersion times}

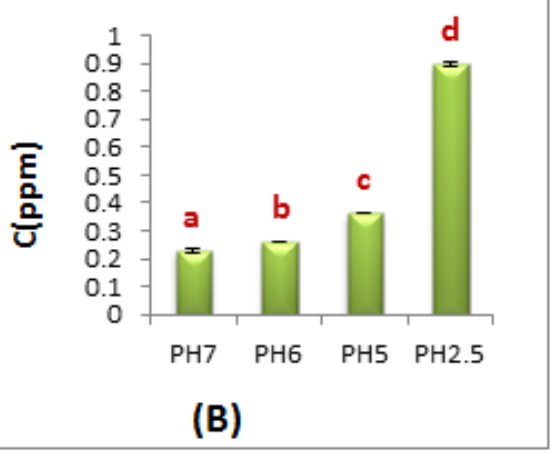

(A)

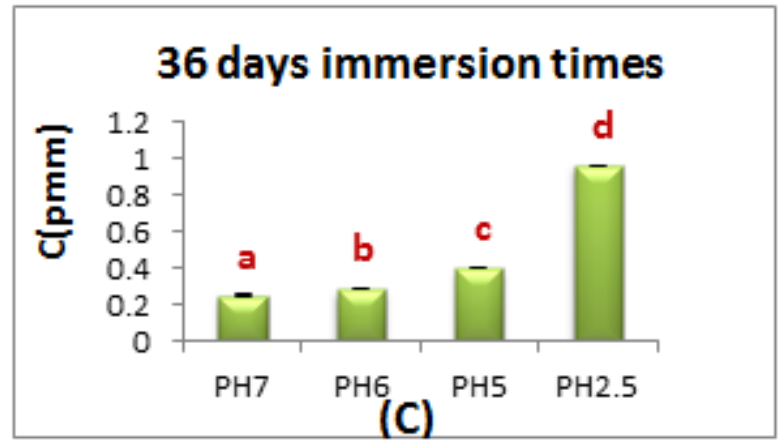

Figure(1):mean, \pm standerd deviation and Multiple Comparisons of $\mathrm{Cr}$ release $\mathrm{s}$ in solution dependent on the $\mathrm{pH}$ after various immersion times, (A:12 days immersion time,

B: 24days immersion time,C: 36 days immersiontime). 
Table (2): Anova of $\mathrm{Cr}$ ion release after different immersion times.

\begin{tabular}{rccccc}
\hline & Sum of Squares & df & Mean Square & F & Sig \\
\hline Cr-12 Between Groups & 1.056 & 3 & .352 & 20539.435 & .000 \\
With Groups & .000 & 12 & .000 & & \\
Total & 1.056 & 15 & & & \\
Cr-24Between Groups & 1.180 & 3 & 393 & 227507.99 & .000 \\
With Groups & .000 & 12 & .000 & & \\
Total & 1.180 & 15 & & & \\
Cr-36 Between Groups & 1.360 & 3 & .453 & 324692.10 & .000 \\
With Groups & .000 & 12 & .000 & & \\
Total & 1.360 & 15 & & & \\
\hline
\end{tabular}

$B$-Nickel ion releases:

The value of mean of Ni ion release (pmm), \pm standard deviation, Dennett's test and Duncan Multiple analysis rang test of control, and three immersion solutions artificial saliva with different $\mathrm{pH}(7 \mathrm{as}$ control,6,5 and 2.5) after various immersion times are shown in Figure (2). After 12, 24 and 36 days of immersion, Ni ion release in small amount in solution with $\mathrm{pH}(6,5)$ respectively, while in $\mathrm{pH} 2.5$ re- lease in large amount $(2.01,2.61,3.012$ ppm) respectively when compare with control pH7 as shown in Figure(2). Ni ion release showed a statistically significant difference at $\mathrm{p} \leq 0.05$ between three immersion solutions after various immersion times as shown in Table (3). It should be mentioned that nickel ion release has been found more release than chromium as shown in Figure $(1,2)$.
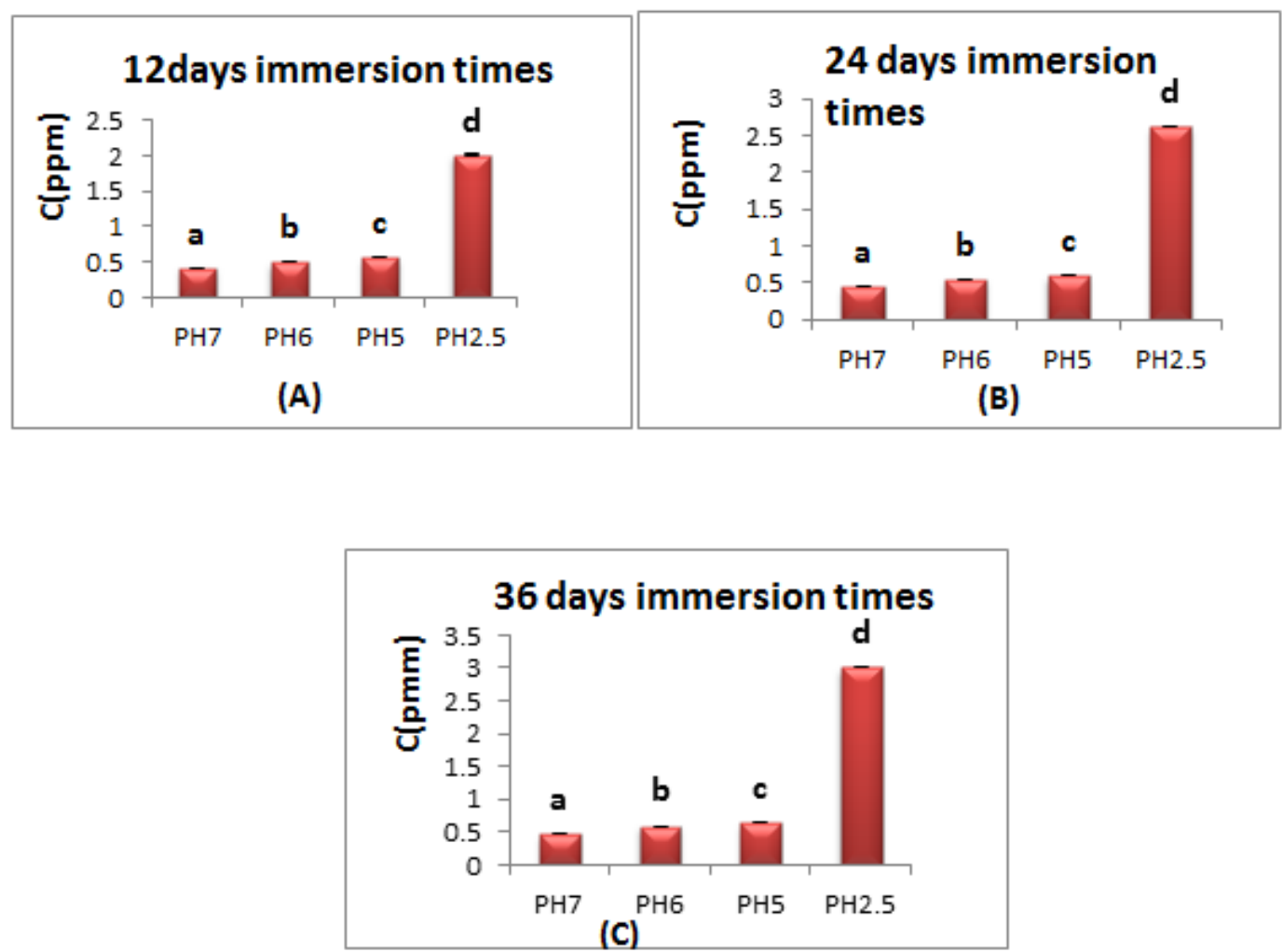

Figure(2): mean, \pm standerd deviation and Multiple Comparisons of $\mathrm{Ni}$ ion release in solution dependent on the $\mathrm{pH}$ after various immersion time, (A:12 daysimmersion time,

B: 24 days immersion time,C: 36 day simmersion time). 
Table (3): Anova of $\mathrm{Ni}$ ion releaseafter different immersion times.

\begin{tabular}{rccccc}
\hline & Sum of Squares & df & Mean Square & F & Sig \\
\hline Cr-12 Between Groups & 9.490 & 3 & 3.163 & 186534.95 & .000 \\
With Groups & .000 & 12 & .000 & & \\
Total & 9.490 & 15 & & & \\
Cr-24Between Groups & 12.876 & 3 & 4.292 & 2395572.5 & .000 \\
With Groups & .000 & 12 & .000 & & \\
Total & 12.876 & 15 & & & \\
Cr-36 Between Groups & 21.057 & 3 & 7.019 & 10528552 & .000 \\
With Groups & .000 & 12 & .000 & & \\
Total & 21.057 & 15 & & & \\
\hline
\end{tabular}

\section{DISCUSIONS}

Dental casting alloy should not be toxic, which means that they should not chemically react with either acids or alkaline solutions when a prosthetic appliance is inserted into the oral cavity dental alloy, is in contact with saliva. Saliva is a hypotonic solution and good conductor of electricity, Metal ions which are released from dental alloys in the humid oral cavity medium can lead to allergic responses. Furthermore, there by causing different changes base metals. $^{(12,13,14,15)}$

Results showed that the artificial saliva (pH2.5) showed a significantly and higher rate of $\mathrm{Ni}$ and $\mathrm{Cr}$ release at $\mathrm{p} \leq 0.05$ than artificial saliva with $(\mathrm{pH}$ 7as contro,6,5) after various immersion times as show in Figures $(1,2)$.

All three observed parameters, chemical composition of the alloy, $\mathrm{pH}$ value of the artificial saliva, and time of exposure to the solution influenced ion release. Statistically significant stimulation of ion release at lower $\mathrm{pH}(\mathrm{P}<.05)$, which is in line with the hypothesis that organic acids in dento bacterial plaque affect the release of ions, emphasizes the major role of oral hygiene in minimizing corrosion. ${ }^{(13,16,17)}$ The finding of ( Majak, et al, Elshahawy,et al) was concluded that levels of released ions were gradually increased with decreasing solution $\mathrm{pH}$. This occurred because the acidic condition provide a reducing environment in which the oxide film required for corrosion resistance is less stable. The $\mathrm{pH}$ and period interactions were statistically significant, highest amount of ion release occurred after 60 days of immersion for every alloy in artificial saliva of pH 2.3 and lowest in
$0.9 \%$ saline solution. It was concluded that ion release from alloys was $\mathrm{pH}$ dependent. $(6,18)$ Our study determined that, the greater amount of element release of $\mathrm{Ni}$ from $\mathrm{Ni}-\mathrm{Cr}$ alloy as compared to $\mathrm{Cr}, \mathrm{Cr}$ release from the Ni-Cr alloy were much lower in comparison to the release of $\mathrm{Ni}$ in artificial saliva, could be related to the lower content of $\mathrm{Cr}$ in its composition of alloy,the amount of element release increased with increasing conditioning, times, this finding agreement with other reseaeches. ${ }^{(1,19,20,21)}$ While our finding disagree with the result of (Duffo, et al,Menek, et al) who showed that nickel ion release was decreased with increasing $\mathrm{pH}$ of the different liquids is independent on the $\mathrm{pH}$ of the solution in all time periods. Finaly in the present study, quantities of Ni eleased from $\mathrm{Ni}$ based alloy in the four different immersion media were markedly below the average dietary intake of (200-300 $\mu \mathrm{g} /$ day), and average dietary intake of $\mathrm{Cr}$ is $280 \mu \mathrm{g} / \mathrm{day}$, this agreement with the results of ( Bhaska and Reddy).

\section{CONCLUSIONS}

There is an evidence that there is $\mathrm{Ni}$ and $\mathrm{Cr}$ ions release from $\mathrm{Ni}-\mathrm{Cr}$ alloy at the presence of different acidity of artificial saliva, $\mathrm{Cr}$ and $\mathrm{Ni}$ ion release in small amount in solution with $\mathrm{pH}(6,5)$, while in $\mathrm{pH} 2.5$ release in large amount after (12, $24,36)$ days of immersion. Amount of metals released from $\mathrm{Ni}-\mathrm{Cr}$ alloy in artificial saliva, was significantly below the average dietary intake and did not reach toxic concentrations. Nickel exhibited the highest level of ion release and $\mathrm{Cr}$ the lowest level. Alloy type, $\mathrm{pH}$ and alloy $\mathrm{pH}$ interaction each affected the degree of release of the ions. 



\section{REFRERNCES}

1. Denizoglu S, Duymus Z and Akyalcin $S$. Evaluation of Ion Release from Two Base-metal Alloys at Various pH Levels. $J$ of Inter. Med. Rese. (2004). 32:33-38.

2. Seda G. Comparision of metal release from new and recycled bracket archwire combinations. Angle Orthod. (2005). 75(1):92-948.

3. Majak K, Pavlin D, Slaj M, Varga S, Lapter M, Slaj M. Type of archwire and level of acidity: effects on the release of metal ions from Orthodontic appliances. Angle Orthod. (2009). 79(1):102-10

4. ElshahawyW, Watanabe I, Koike M. Elemental ion release from four different fixed prosthodontic materials. Dent Mater.(2009).25(8): 976-

5. Duffo S, Farina B. Corrosion behavior of a dental alloy in some beverages and drinks. Material chemistry and physics.( 2009). 115(1): 235-8. 81.

6. Sagesen L, Ergun G, Karabulut E . Ion release from metal-ceramic alloys in three different Dental media. Materials Journal.( 2011). 30(5): 598-610

7. BhaskaV, Reddy V. Biodegradation of nickel and chromium from space maintainers: an in vitro study. $J$ Indian SocPedod Prev Den. (2010).28

8. Tajima K, Miyawaki A, Nagamatsu Y, Kakigawa $\mathrm{H}$ and Kozono $\mathrm{Y}$. Electropolishing of titanium and its alloys for miller finishing. $J$ pn Dent $M a-$ ter.(2005); 24(406): 60-64.

9. ISO 10271 Standard. Dental metallic materials corrosion test methods.;1st ed, Switzerland: ISO Geneva (2001).

10.Wataha J . Biocompatibility of dental casting alloys: a review. J Prosthet Dent.(2000).83: 223-234.

11.Stajer A, Ungvari K, Istvan K. PelsocziM, Polyanka H, OszkoA and TurzoK.Corrosive effects of fluoride on titanium: Investigation by X-ray photoelectron spectroscopy, atomic force microscopy, and human epithelial cell culturing. J Biomed Mater Res Part A.(2008).51-458.

12.Faccioni F, Franceschetti P, Cerpelloni M, Fracasso E. In vivo study on metal release from fixed orthodontic ap- pliances and DNA damage in oralmucosa cells. Am J Orthod Dentofacial Orthop. (2003). 124(6):687-93.

13.Can G., Akpinar G., AhmetA. The Release of Elements from Dental Casting Alloy into Cell-Culture Medium and Artificial Saliva. Eur J Dent. (2007). 1(2): 86-90.

14. Wylie C, Shelton R, Fleming G, Davenport $A$. Corrosion of nickel-based dental casting alloys. Dent $\mathrm{Ma}$ ter.(2007). 23: 714-7.

15.HussienA and Al-Mulla A .The effect of food simulants on corrosion of simulated fixed orthodontic appliance. JBaghColl Dentistry.(2010). 22(1):6875.

16.Huang H, Ding J, Yan M, Kao T. Metal ion release from new and recycled stainless steel brackets. Eur $J$ Orthod.(2004);26(2):171-7.

17. Manaranche C, Hornberger H. A proposal for the classification of dental alloys according to their resistance to corrosion. Dent Mater.(2007).23: 14281437.

18.Karnam S, Reddy A and Manjith C. Comparison of Metal Ion Release from Different Bracket Arch wire Combinations: An in vitro Study. $J$ Contemp Dent Pract (2012).13(3): 376-38.

19.Stipetic J ,Celebic A ,BauclcI,Rincic N ,Catic A ,Bauclc $M$.The Release of Nickel Ions from Three Different Dental Casting Alloys . ActaStomatol Croat(2003).Vol. 36, br. 4.

20.Nejatidanesh F ,Savabi O,Yazdanparast A . An Investigation on Metallic Ion Release from Four Dental Casting Alloys Journal of Dentistry, Tehran University of Medical Sciences, Tehran, Iran.( 2005); Vol: 2, $\mathrm{N}$

21.Haddad A ,Tortamano A , Souza A ,Oliveira P. An in vitro comparison nickel and chromium release from bracket; Braz Oral Res; Oct-Dec. (2009). 23(4): 399-406.

22. Menek N , Basaran S, Karaman Y ,Ceylan G , Tunc E , Investigation of Nickel Ion Release from Stainless Steel Crowns by Square Wave Voltammetry. Int. J. Electrochem. Sci.(2012).64656471. 